\title{
PERFIL DO ADMINISTRADOR PÚBLICO, NO BRASIL
}

\author{
Floriano Freitas Filho \\ Professor do Curso de Mestrado em Administraçāo \\ Universidade de Brasflia
}

Em meados de 1988, o Brasil todo assistiu, na TV, depoimento de prefeito de típica cidade interiorana brasileira de pequeno porte, sobre o porquê empregara toda sua família nos mais diversos postos da Prefeitura. Afirmou convicta e serenamente ao seu entrevistador: - "por que nāo empregar meus parentes? nāo vou empregar os dos meus adversários!"

Uma das frases mais conhecidas do repertório polf́tico nacional enfatiza pensamento análogo: - "aos amigos tudo, aos adversários a lei", corolário da célebre "lei, ora lei!"

Não apenas juristas reconhecem que nosso Direito Positivo $€$ farto e abrangente. Hă preceitos para tudo, que se aplicados, obedecidos ou cumpridos fariam de nossa Democracia uma das mais perfeitas e invejáveis do mundo, já que nāo se pode conceber Democracia sem Direito.

No entanto, institucionalizamos algo de notável: o "jeitinho brasileiro", hermenêutica própria daqueles que procuram cumprir norma de direito minimizando seus aspectos formais ao essencial e nos limites extremos do possfvel, a fim de maximizar interesses particulares. Essa prática nāo é de hoje. De há muito está enraizada em nossa cultura. Caracteriza traço dos mais pitorescos do nosso modo de ser, detectável em qualquer parte do País.

Jóia desse modo de ser, revela-nos PALACIN( (I); - "Dentro da divisão dos reinos portugueses, às minas estava-lhes proibido a fabricaçāo do aguardente. Nāo era tanto uma medida mercantilista de proteçâo dos vishos da Metrópole, como às vezes costuma interpretar-se, senảo uma forma de evitar a distraçāo de braços das

(1) PALACIN, Luiz, O sécula de ouro em Goiás. 3 cd. Brasflita, INL, 1979, p. 37

R. Serv. Publ. Brasilia, 117 (1): 77-84, jun./set. 1989 
minas para o cultivo da cana. Esta proibição nunca foi muito respeitada. Quando o governador D. Luis de Mascarenhas chegou a Goiás (1739) encontrou engenhos e engenhocas espalhados por todo o pafs. Procurou nāo tomar conhecimento de sua existência. Mas ali estava o procurador das entradas - os engenhos diminuiam os direitos cobrados nos registros - para recordar-lhe sua obrigação uma e outra vez. Acossado, o govemador achou um meio de conservar os engenhos, apesar da proibiçăo, e satisfazer, ao mesmo tempo, os direitos do contratador pediu aos engenhos que pagassem aos fiscais das entradas os direitos de sua própria aguardente, como se fosse importada."

Seria possivel traçar o perfil do administrador público brasileiro? Haveria traços caracteristicos de um padrăn de comportamento comum em todo o territónio nacional?

GIOVANNI VICO, em sua obra "Princlpios de uma ciência nova sobre a natureza comum das naçōes, através da qual também se revelam novos princlpios da lei nafural dos povos" já enunciara, há mais de duzentos e sessenta anos (1725), que "...o mundo social é certamente obra do homem; e daí segue-se que se pode e deve encontrar os princípios desse mundo nas modificaçōes da própria inteligência humana". E prossegue: - "os govemos se adaptam necessariamente à natureza dos govemados; sảo resultado mesmo dessa natureza". Em outras palavras, "a humanidade cria a si propria"

Ao tentar-se traçar o perfil do administrador público - ou do govemante nāo se pode esquecer que se está indagando sobre realidade que se difenencia no tempo e no espaço, e, por vezes, com grande rapidez. Afinal, administra-se organizaçōes, c as organizaçōes são organismos vivos, que têm história, cada uma a sua.

A sociedade ê a síntese final das organizaçōes que a compōem. O Estado, expressāo formal da sociedade, 6 , pois, realidade historicamente constiturda que se modifica com a evoluçāo cultural de cada um de seus cidadāos. Nesse sentido, a organizaçāo Estado, por si só e pelas organizaçōes que o compōem, dade cultural.

Traçar o perfil do administrador público brasileiro é, pois, adentrar o campo da cultura. Ê por em evidência a açäo criadora do homem, subordinando a natureza a seus fins, partindo da própria natureza.

Nâo se trata de indagar-se, aqui, sobre o conceito de cultura - no sentido antropológico nu n'outro qualquer. Seja ele qual for - e o são muitos - o fato é que a "cultura é como uma lente através da qual o homem vê o mundo"(2). Diferentes homens, diferentes culturas, diferentes lentes, diferentes visöes das coisas. Assim o é, também, na administraçăo pública, principalmente no Brasil, cuja característica histórico-cultural é a heterogeneidade

Nảo obstante, assim como detectamos o "jeitinho brasileiro" como um dos

(2) Pensamento de Ruth Benedict citado por LARAlA. Roque de Barms, in: CULTURA: um conceilo antropológico. Rio de Janeiro, Zahar, 1986. 
traços comuns do modo de ser do brasileiro e, pois, do administrador público brasileiro em todo o território nacional, há outros traços comuns que igualmente caracterizam um comportamento nacional. Tais traços histórico-culturais derivam, geralmente, de peculiaridades de nossa colonizaçāo, das dimensōes continentais de nosso território, da aculturaçâo rápida das várias correntes migratórias que compōem o brasileiro de hoje, da miscigenaçāo quase sem entraves de diversas culturas que se mesclaram em nosso território por quinhentos anos, de nossa evoluçāo econômico-finnanceira dependente e de periferia em relaçāo ao resto do mundo, e de nosso desenvolvimento desigual inter e intra regiōes, inter e intra pessoas.

Alguns desses traços săo bem característicos: um nacionalismo típico de ilhéus, já que somos cercados por água de norte a sul, no lado leste, e por florestas, pântanos, cerrados e outros vazios culturais, no lado oeste; uma tendência à burocratizaçăo administrativa herdada do centralismo português que, ao impor a forma como condiçāo de confiabilidade, se degenera no trafico de influência, no empreguismo, no compadrio, no nepotismo, no servilismo, na servidāo a grupos e no primado do interesse individual sobre o social: um administrar contra e apesar de formalismos inconseqüentes (que o digam os dirigentes de quaisquer niveis, ao elaborarem, por obrigaçāo, seus orçamentos anuais - peças cerebrinas de acomodamentos numéricos); um administrar pessoas impostas, num ritual de fatos consumados que culminam num acomodamento estéril ou impmdutivo, altamente oneroso à Naçăo; um etemo administrar com escassez de recursos financeiros, inviabilizando qualquer planejamento estratégico; um horror a mudanças pela forte tendência à inêrcia das situaçōes criadas e por vezes institucionalizadas; em suma, um alheiamento e mesmo descaso das técnicas da Administraçāo eficiente, eficaz. e efetiva. Tal quadro se evidencia no distanciamento cada vez maior entre o discurso e a ação de nossos homens públicos, polf́ticos ou dirigentes.

A expressão "cuItura", na Ciência da Administraçăo, reveste-se, hoje, daqueles modismos acadêmicos típicos de nosso Pars. Diz tudo o que se pensa querer que se diga, sendo elegante, mas poucos compreendem seu significado e real abrangência.

Cultura é história; sāo valores. Assim como hoje se pensa o "culturalismo jurfdico" é possível pensar-se a "culturalismo administrativo". Impossível é compreender a Administração sem referibilidade a um sistema de valores em virtude do qual se estabeleçam relaçōes de administradores para administrados, de governantes para govemados, com exigibilidade bi ou multi-lateral de fazer ou nāo fazer alguma coisa.

Para MIGUEL REALE "culturalismo ê uma concepção do Direito que se integra no historicismo contemporâneo e aplica, no estudo do Fstado e do Direito, os princfpios da Axiologia, ou seja da teoria dos valores em função dos graus de evoluçäo social".(3)

(3) REALE, Miguel. Teoria do Direito e do Estado. 4 ed. Săo Paulo, Saraiva, 1974, p.8.

R. Serv. Publ. Brasdia, 117 (1): 77-84, jun./set. 1989 
Esse mesmo conceito aplica-se a "culturalismo administrativo", substituindo-se a palavra Direito por Administração e compreendendo-se Estado como expressāo formal da sociedade, vista esta como síntese final das organizações que a compōem.

Isso posto, traçar o perfil do administrador público brasileiro é desafio bem maior que o simples traçar de algumas características comuns a nossos governantes ou dirigentes públicos, cada um influenciado por seu respectivo ambiente. $\hat{\mathbf{E}}$, sobretudo, traçar seu perfil cultural. Dificilmente o pesquisador que se dispusesse a tal tarefa chegaria a um denominador comum. Teria de huscar tipologia que se assentaria na própria tipologia da cultura brasileira. Imenso desafio.

A cultura administrativa ${ }^{(4)}$, inerente ao administrador, diferencia-se no tempo e no espaço. Decorre de processo histórico: longo processo dialético de implica§̧ão e polaridade entre fenômenos administráveis e valores. Um mesmo fenômeno, hoje, será diferentemente administrado nos vários Brasis que compōem a sintese final que denominamos Brasil. O fenômeno pode ser o mesmo, mas diversas (e quão diversas) são as culturas daqueles que irăo decidir sobre ele, a qualquer nível institucional, público ou privado.

Cada administrador com seus valores. Ora, diferentes valores, diferentes interpretaçōes dos fenómenos; logo, diferentes decisōes. Diferentes decisōes, diferentes cursos de ação. Seria ingenuidade acadêmica ou perigosa falácia admitir-se uma cultura nacional homogênea, quanto mais a que se associe à Administração Pública.

A cultura administrativa, no setor público, tenderia a homogeneidade se o Direito Positivo fosse aplicado com rigor? se houvesse controle rígido dos resultados da açāo administrativa, em todos os niveis, por parte dos diferentes órgãos de fiscalizaçăo e controle?

A questão não é tão simples.

Valores não se adquirem no dia-a-dia. Cultura não se institucionaliza nem se exorta por lei. Há um longo processo histórico de sedimentação de posturas administrativas calcadas em experiências próprias ou em exemplos de erros e acertos de outros, no conhecimento difundido sobre sançŏes premiais e penais a bons e a maus administradores, na capacidade de observação das reais necessidades públicas, na sensibilidade às mudanças para melhor, na agudeza de espírito público para detectar o que deva ser esse melhor e quais os valores sociais que se sobrepōem aos meramente individuais.

De pouco adiantarão as melhores e mais avançadas constituições federal, estaduais e municipais para dotar o País de administradores públicos excepcionais capazes de alterar a “personalidade” das organizaçōes. Muito pelo contrário, é bem provável que, de imediato, amplie-se o folclore do "jeitinho brasileirn".

Mas não se pode relegar a segundo plano a importância da sistematizaçāo de alguns dos novos valores da sociedade brasileira, expressos nesses estacutos le-

(4) Não se coniunda com "cultura organizacional": modo de vida ou sistema. 
gais. Afınal, constituem eles verdadeiros faróis orientadores de açōes administrativas, balizando a desejável - o que deve ser. De resto, confie-se na história, na inexorabilidade da conspiraçāo dos fatos ou na natural tendência do ser humano de lutar pelo melhor, pelo socialmente melhor.

Isso posto, é bastante diff́cil traçar um perfil do atual administrador publico brasileiro, ainda que o apenas desejável. Talvez seja possível fazê-lo, desde que se tenha consciência de quāo limitada seria sua aplicabilidade, pois somente por acaso seria ele identificável em nossa sociedade. Não se pode prescindir, porém, de um padrăo ideal que se preste a comparaçōes das quais derivaria qualquer tentativa de tipicação.

De uma maneira geral, o perfil ideal do administrador público brasileiro coincide com o de qualquer administrador. A literatura especializada e farta a respeito e nāo foge ao que já se situa como lugar comum. Dependenda do nfvel que o administrador ocupe na organização - de primeira linha (supervisor), intermediário ou de alta administraçăo - será maior ou menor à exigência de alguns predicados comuns.

A fim de que se tomem evidentes as naturais diferenças necessariamente detectáveis num esforço de tipificaçāo, tais predicados sāo agrupáveis, e por vezes se repetem, em três grandes categorias, as quais melhor se conformam ao conceito de cultura - em última análise, o fator diferenciador por excelência: 1. sensibilidade humana; 2 . sensibilidade profissional e 3 . sensibilidade pública.

A sensibilidade humana decorre do indivfduo como pessoa; ele como resultante do mein social em que viveu e vive, se educou, socialmente se formou. Traduz sua capacidade de inter-relacionar-se com outras pessoas, compreendendo suas necessidades, suas exigências, seus valores, suas mativaçōes. Dela decorrem capacidades intrínsecas a cada administrador: de liderança, de comunicação, de coordenaçāo de interesses dos que nele confiam e dele dependem, de negociaçāo e de mediaçāo. Afinal, o administrador é, sobretudo, um condutor de homens, interagindo-os com bens materiais e imateriais, no propósito de conduzir a organização à realização de seus fins, consetâneos com os fins da sociedade em que está inserida.

A sensihilidade profissional decorre do indivíduo como profissional da administraçāo. Em outras palavras, de sua competência técnica na arte/ciência da Administraçāo, quer seja ela assentada na sua particular experiência de vida, quer seja ela adquírida por sua educaçāo formal (universitária ou nāo). $O$ ideal é que decorra de ambas.

Pela competência técnica, tal sensibilidade se aguçaria por força da compreensāo da imensa responsabilidade que pesa sobre cada um de seus atos, o que se traduz por duas outras compreensōes fundamentais: a da necessidade de prestar contas à sociedade que the financia e que the delega todos os poderes de que dispöe; a das dificuldades que envolvem os processos de análise diagnóstica e equacionamento de problemas administrativos, tanto no conceituar situaçōes ideais factiveis, quanto no priorizar altemativas dentro do legitimamente possivel. 
Dessas compreensōes derivaria a maior probabilidade de se tomar decisōes justas, eficientes, eficazes e efetivas, maximizando os interesses do extrato social afetado por tais decisŏes e minimizando privilégios ou interesses particulares.

Seria o saber associado ao saber fazer, ao querer fazer e an poder fazcr. Mas fazer o que? Mudar: mudar para melhor, um melhor halizado por valores que fundamentam a razāo de ser do extrato social em que o administrador está inscrido.

Nessa ordem de idéias, destacam-se alguns predicados gerais do administrador: 1. senso de responsabilidade social: 2 . coordenador de interesses os mais diversos; 3. avaliador de situaçôes e de resultados: 4. supervisor; 5 . negociador; 6. multi-especialista ou 7. generalista.

A sensibilidade pública decorte do indivíduo como cidadāo; de sua educação e vivência cf́vica, ou seja de sua cultura como "homo politicıs", amálgama do "homo economicus" com o "homo juridicus" e com quantos mais "homos" as ciências sociais pretenderem ou puderem tipificar. F́ essa sensibilidade que, sobretudo, o diferenciará como administrador público. Dela depende sua capacidade de conduzir ao equilfbrio objetivos concorrentes e estabelecer prioridades. Dela depende, outrossim, sua eficiência e eficácia como planejador, executor, negociador, mediador, polftico e diplomata, dê-se a esses termos os significados que se quizer. $O$ importante $e$ que esses predicados permitam que o administrador conduza a organização, o mais efetivamente ${ }^{(5)}$ à realizaçāo de seus desideratos próprios, sem fugir aos fins da sociedade em que ela se insere. Tanto maior e mais ampla essa sensibilidade, tanto maior e mais ampla sua dimensāo como adminisrador, como homem público.

Planejador, generalista, investigador, multi-especialista, mediador, político, diplomata, responsável, lider, condutor, dirigente eficaz, eficiente e efetivo, além de trahalhador - pouco importa! Tudo isso e algo mais que se possa idealizar devem mesclar-se na interaçāo contfnua e dinâmica dessas três sensibilidades, que mútua e crescentemente se implicam: a humana, a profissional e a pública.

Essa interação é, em suma, processo que se confunde com o próprio processo cultural do indívuo, da pessoa, do profissional, do cidadāo, das organizaçóes, do povo, da regiāo, de toda uma naçāo.

Quanto mais crescente, consistente e completa essa interação cultural, mais próximo estará o administrador público do estadista, tāo desejado e sonhado por todos os hrasileiros de hoje; quanto menos... a TV que nos continue mostrando os tipos estranhos que este País vem gerando em seus quadros diretivos, em todos os niveis organizacionais.

Em artigo publicado na Revista do Serviço Público (ano 43, vol. 1 14, nº 5 , jan./fev. 87, p.29) - Dilema: administrar com ou contra preços - delineamos um perfil de administrador público: "alguém distanciado da estreiteza do tecnobu-

(5) Utiliza-se efetivamente em decorrência do conceito de efetividade: arrıbuto da administraçāo que melhor se aproxime, na realizaçāo de seus objefivos de produçâo e desempenho, dos objelos de sua clientela (ou usuários). 
rocrata, da limitaçāo do especialista professoral ou do apenas prático; alguén eclético, perspicaz, com vivência tanto do mundo da burocracia pública (defensora da sociedade), quanto do mundo da iniciativa privada (impulsora da sociedade), seja qual for sua formação profissional" ..." "sem medo de errar, com o firme propósito de acertar, negociando e conduzindo suas decisōes"'...na escassez de recursos... "com preços de mercado, com as reivindicaçōes salariais, com os sindicatos livres, com as greves - com tudo, enfim, que expresse, naturalmente, o que a sociedade quer, indicando o que é prioritánio e o que é possível de se fazer".

Da mesma forma, e possível traçar o perfil do anti-administrador público: mesquinho, personalista, com total ausência de sensibilidade pública, a nāo ser no estritamente necessário para a manutençăo ou progressāo de seu status; bajulador daqueles que the convêm; exf́mio manipulador da mentira polftica: paciente $e$ inconseqüente no administrar com n tempo, sem assumir posiçōes ou tomar partidos; oportunista negociador em causa própria; enraizado no poder a qualquer custo: burocrata por conveniência, perito na alquimia da malversaçāo dos recursos públicos:... e, via de conseqüểncia, vaidoso, na sua auto-idolatria.

Síntese final da cultura administrativa dos que a direcionaram e, hoje, a direcionam, cada organizaçāo com sua cultura. Novas culturas, possíveis mudanças. Não há estagnação: tudo muda, para melhor ou para pior, dependendo de novos administradores. 